MATTHEW E. GRUWELL $(*)\left(^{\circ}\right)$ - SKYLAR WOOLMAN $\left(^{*}\right)$ - TAKUMASA KONDO $(* *)$

\title{
PHYLOGENETIC PLACEMENT OF THE WHITE COCONUT SCALE, PARLAGENA BENNETTI WILLIAMS (HEMIPTERA DIASPIDIDAE) $\left({ }^{1}\right)$
}

\author{
(*) Penn State Behrend, Erie, Pennsylvania, USA. \\ (**) Corporacion Colombiana de Investigación Agropecuaria (Corpoica), Palmira, Valle, Colombia. \\ $\left(^{\circ}\right)$ Corresponding author: meg26@psu.edu
}

Gruwell M.E., Woolman S., Kondo T. - Phylogenetic placement of the white coconut scale, Parlagena bennetti Williams (Hemiptera Diaspididae).

Parlagena bennetti Williams (Hemiptera: Diaspididae) is commonly known as the coconut scale and has only been collected in some islands in the Caribbean, Central America and the northernmost countries of South America. The species $P$. bennetti has been placed in Parlagena, a genus of few species currently considered as closely related to Parlatoria Targioni Tozzetti, but it has never been involved in molecular phylogenetic analysis. Here we include data from three genes of $P$. bennetti with 32 other armored scale insects and one outgroup to determine the correct placement of this species among armored scale insects. Both combined analysis and individual genealogies demonstrate the probable placement of this species in the subfamily Diaspidinae, likely as part of the tribe Lepidosaphidini.

KEY WoRDS: armored scale, coconut pest. Diaspidinae, Lepidosaphidini, phylogeny.

\section{INTRODUCTION}

Parlagena bennetti is an armored scale insect known as the coconut scale that was originally described by WiLLIAMS (1969) when it was collected on coconut in the Caribbean island of Trinidad. In the description paper, WiLliams (1969) was hesitant to include this species within the genus Parlagena because it possesses perivulvar pores; all other three species of Parlagena lack perivulvar pores and this character state is considered to be a key character for the genus. Despite the presence of perivulvar pores, Williams (1969) placed the species in Parlagena due to simple and reduced plates that are indistinct and fragile. WILLIAMS (1969) noted some parlatoriine characters and thus placed it within Parlagena, a genus thought to be closely related to Parlatoria.

Parlagena bennetti is an economically important pest of coconut palm plantations, Cocos nucifera L. (Arecaceae) on San Andres Islands (Colombia) (MosquerA, 1976, 1977), Trinidad (Williams, 1969) and the Bay Islands (Honduras) (Evans \& Dooley, 2013). There have also been heavy infestations in oil palm plantations in La Ceiba, mainland Honduras (BustiLlo et al., 2015), and officials of the National Palm Farmers Federation of Honduras (Fenapalmah) claim that the species is distributed throughout much of Honduras (Bustillo et al., 2015). In Colombia, this insect was first reported on San Andres Island where it is considered a pest of coconut (MOSQUERA, 1976, 1977). Recently, P. bennetti was reported in mainland Colombia causing serious damage in an oil palm (Elaeis guineensis Jacq.) plantation, being associated with an entomopathogenic fungi of the Pestalotiopsis complex (Bustillo et al., 2015).

\footnotetext{
${ }^{1}$ Original scientific contribution presented and discussed at XIV International Symposium on Scale Insect Studies, Catania-Italy, 13-16 June 2016.
}

Its known distribution includes Colombia (San Andrés \& Providencia Islands in the Caribbean, and the departments of Santander and Valle del Cauca in the mainland), Honduras (Bay islands), Trinidad \& Tobago (Trinidad) and Venezuela (Lara State) (Bustillo et al., 2015). Known host plants include coconut palm; New Zealand flax, Phormium tenax J.R. Forst. \& G. Forst. (Xanthorrhoeaceae); Manila palm, Veitchia merrillii (Becc.) H.E. Moore; oil palm, Elaeis guineensis L.; an oil palm hybrid $\mathrm{OxG}$, E. oleifera and E. guineensis (Arecaceae) (KoNDO et al., 2015); and bamboo palm, Dypsis lutescens (H. Wendl.) Beentje \& J. Dransf. (BustiLlo et al., 2015). It was originally reported as a pest species of coconut showing significant damage to leaves and fruit (WILLIAMS, 1969). Its potential for inflicting significant damage was recently confirmed by BustiLlo et al. (2015) and Kondo et al. (2015). Greatest damage is done to coconut and oil palm. The species may be found in large numbers on the leaves of the other recorded host plants, but the extent of its damage is unknown. WiLLIAMS (1969) reported the presence of males, meaning that the species is, at least in part, sexual. Williams (1969) describes the scale of the adult male as being about $1.0 \mathrm{~mm}$ long, elongate, with subparallel sides, of the same downy consistency as the female scale, with pale yellow exuviae. The third author (TK) also observed the presence of male puparia and verified the presence of alate males.

Other species from the genus Parlagena include $P$. buxi (Takahashi) previously collected in China and Iran, $P$. mckenziei (Balachowsky) known from Iran and $P$. remaudierei (Kaussari) also only collected in Iran (GARCÍA et al., 2016). Parlagena bennetti has few recent collection records (Bustillo et al., 2015 and Kondo et al., 2015), however, there are no records of incorporation $P$. bennetti into a molecular phylogenetic data set. Like WiLLIAMS (1969), McKenzie referenced this genus as being closely allied to Parlatoria (McKENZIE, 1945) but its phylogenetic placement among armored scale insects remained unknown. Because of this, we elected to test the phylogenetic 
placement of this species within the armored scale insects, utilizing previous data collected and published by the Normark Lab at the University of Massachusetts, Amherst (ANDERsen et al., 2010; Gruwell et al., 2007; Morse \& NORMARK, 2006).

\section{MATERIAL AND METHODS}

Samples of $P$. bennetti were collected at the Colombian Corporation for Agricultural Research (Corpoica), Palmira Research station, in Palmira, Colombia, on oil palm leaves at $03^{\circ} 30^{\prime} 53.7^{\prime \prime} \mathrm{N}$ and $76^{\circ} 18^{\prime} 57.1^{\prime \prime} \mathrm{W}$, ca. 1005 meters above sea level. The scale insect samples were slide-mounted by the third author and identified as Parlagena bennetti Williams through the use of the original description by WiLliams (1969) and a species diagnosis by Kondo et al. (2015). DNA extraction was done from adult females from the same population using a DNeasy Kit (Qiagen Corp) according to instructions, except that samples were incubated overnight and eluted in $100 \mathrm{ul}$ of $\mathrm{H}_{2} 0$, following protocols designed in the Normark Lab (ANDERSEN et al., 2010). DNA voucher specimens are deposited in the Gruwell Genetics Lab Insect and DNA Collection at Penn State Behrend, Erie, PA, USA. The three genes used for phylogenetic analysis were the bacterial endosymbiont small ribosomal subunit (16s) rRNA, the host insect large ribosomal (28S) rRNA and host Elongation Factor 1 alpha (EF1-alpha). PCR of 28S and Ef1-alpha, including primers, was modeled after wet lab work from ANDERSEN et al. (2010). PCR of 16S, including primers, followed GRUWELL et al. (2007). Technical information can be found in those references.

All additional sequences used, not belonging to $P$. bennetti, were extracted from Genbank (BENSON et al., 2013) using a broad sampling of armored scale insects. The phylogenetic tree provided by ANDERSEN et al. (2010) was used as a guide to determine which samples would be most beneficial for this analysis. Sequence data from three partial genes was compiled, aligned, and analyzed individually and together as a combined analysis. 28S and Ef1-alpha data sets had a total of 34 taxa, including $P$. bennetti whereas $16 \mathrm{~S}$ was missing data from some of the species used and so totaled 26 species. A list of the species used can be found in the combined analysis tree (Fig. I). The outgroup for host data was Thysanococcus pandani Stickney and the bacterial outgroup was Brownia rhizoecola Gruwell.

Alignment was completed on individual genes using MAFFT v7 (KATOH et al., 2002), using the E-INS-I refinement method for $28 \mathrm{~S}$ and $16 \mathrm{~S}$ because it is designed for multiple conserved domains and long gaps. The Automatic strategy to determine the best refinement method was used on the EF1-alpha set. All alignments were then edited by eye in Geneious v6.1.6 (KEARSE et al., 2012) to eliminate areas with questionable homology across bases in the alignment. Individual gene alignments were concatenated for the combined analysis. Phylogenetic analysis was done using the MrBayes (RONQUisT \& HuElSENBECK, 2003) plugin in Geneious (KeARSE et al., 2012). Combined analysis was completed using 10,000,000 generations with 500,000 generation burnin. Individual genes were analyzed for 5,000,000 generations with a 300,000 generation burnin. All runs used four chains, and a GTR model of evolution to most closely match analyses done in ANDERSEN et al. (2010). Support values of Bayesian Posterior Probabilities (BPP) were calculated and are attached to the genealogies (Figs. II-IV).

\section{RESULTS}

The most striking result from the combined genes analysis and individual genealogies is the placement of $P$. bennetti within or close to the tribe Lepidosaphidini. The combined analysis includes a polytomy with Howardia biclavis (Comstock) and Lepidosaphes gloverii (Packard) forming a monophyletic clade of the Lepidosaphidini with a BPP of 74 (Fig. I). The same is true of the Ef1-alpha genealogy with a BPP of $50.28 \mathrm{~S}$ and $16 \mathrm{~S}$ rRNA genealogies do not have $P$. bennetti forming a monophyletic clade in the Lepidosaphidini, but they are closely related. All of the genealogies recover the subfamily Diaspidinae as monophyletic, which includes $P$. bennetti with high BPP support values (total data - 100, 16S - 100, 28S - 98, Ef1alpha - 99)

\section{CONCLUSIONS}

All phylogenetic analyses completed in this project support the placement of Parlagena bennetti in the subfamily Diaspidinae, not closely associated with members of the genus Parlatoria which are in the tribe Parlatoriini as part of the subfamily Aspidiotinae. In the original work on the genus, it was thought to be sister to, or closely related to the parlatoriine armored scale insects, because of this assumption; our project heavily favored the use of samples from the genus Parlatoria. According to our analysis, $P$. bennetti is likely in the subfamily Diaspidinae and tribe Lepidosaphidini. Based on morphology of the adult female alone we could not place $P$. bennetti into any known subfamily. Further studies on the morphology of adult males and first-instar nymphs should further elucidate the phylogenetic relation of $P$. bennetti within the Diaspididae.

We cannot make claim to the other species in Parlagena. As mentioned above, WiLliams (1969) was hesitant to place $P$. bennetti in Parlagena. Furthermore, $P$. bennetti is the only species in the genus to be collected in the New World and it was thought to be closely related to Parlatoria. Given this information, collection of other species in the genus will be needed to definitively determine if they are all congeneric and how these species are related to the remaining armored scale insects.

\section{ACKNOWLEDGEMENTS}

The authors would like to thank students from the Gruwell Lab at Penn State Behrend, Robert Light and Behrend Student Research Grants. We are grateful for the hospitality of Corpoica in Palmira, Colombia for hosting Matt Gruwell while he collected scale insects and sorted material. We also thank Jeremy Andersen and the Normark lab for sequencing all the material that was submitted to Genbank and used in these analyses. The third author thanks the Colombian Corporation for Agricultural Research (Corpoica) for funding his participation to the XIV International Symposium on Scale Insect Studies ISSIS, held in Catania - Italy, during June, 13th - 16th, 2016, during which time this paper was presented.

\section{REFERENCES}

Andersen J.C., Wu J., Gruwell M.E., Gwiazdowski R., Santana S.E., Feliciano N.M., Normark B.B., $2010-A$ phylogenetic analysis of armored scale insects 


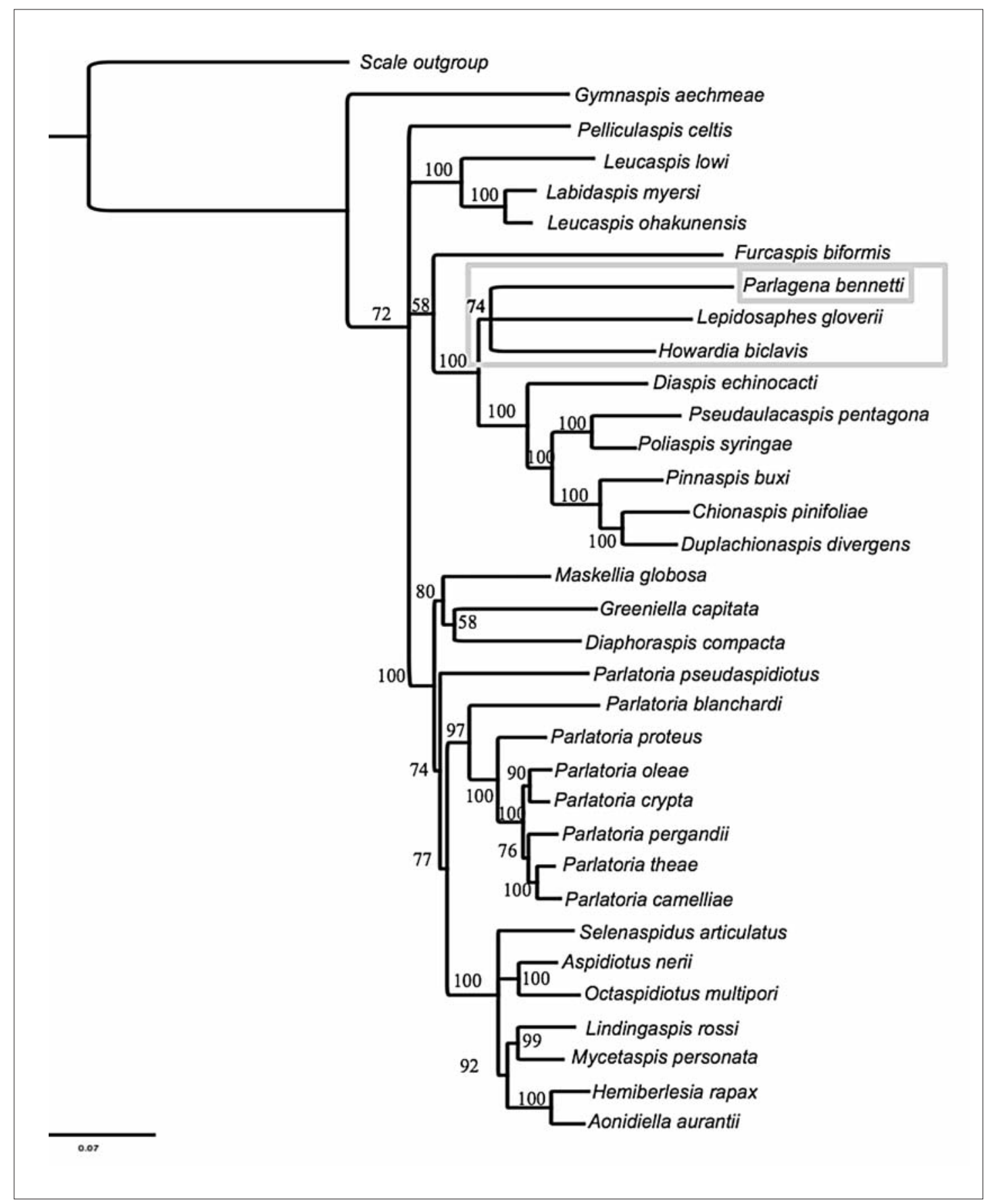

Fig. I - Combined data tree, run using a MrBayes plugin in Geneious. Node labels show Bayesian Posterior Probabilities. The small box highlights $P$. bennetti and the large box highlights other taxa in the tribe Lepidosaphidini.

(Hemiptera: Diaspididae), based upon nuclear, mitochondrial, and endosymbiont gene sequences. - Mol. Phylogenet. Evol., 57(3): 992-1003.

Benson D.A., Cavanaugh M., Clark K., KarschMizRachi I., LipMan D.J., Ostell J., SAYers E.W., 2013 - GenBank. Nucleic acids research, 41(D1), D36-D42.

Bustillo-Pardey A.E., Montes-Bazurto L.G., Kondo, T., 2015 - Detección de la escama blanca del cocotero Parlagena bennetti en palma de aceite Elaeis guineensis en Colombia. - Ceniavances-Cenipalma, No. 181, Agosto 2015. ISSN: 0123-8353. 4 pp.

Evans G.A., Dooley J.W., 2013 - Potential invasive species of scale insects for the USA and Caribbean Basin.
Chapter 18. In: Potential Invasive pests of agricultural crops, Peña J.E. Ed., CABI, UK, pp. 320-341.

García-Morales M., Denno B.D., Miller D.R., Miller G.L., Ben-Dov Y., Hardy N.B., 2016 - ScaleNet: A literature-based model of scale insect biology and systematics. Database. doi: 10.1093/database/bav118. http://scalenet.info.

Gruwell M.E., Morse G.E., Normark B.B., 2007 Phylogenetic congruence of armored scale insects (Hemiptera: Diaspididae) and their primary endosymbionts from the phylum Bacteroidetes. - Mol. Phylogenet. Evol., 44(1): 267-280.

Katoh K., Misawa K., Kuma K.I., Miyata T., 2002 - 


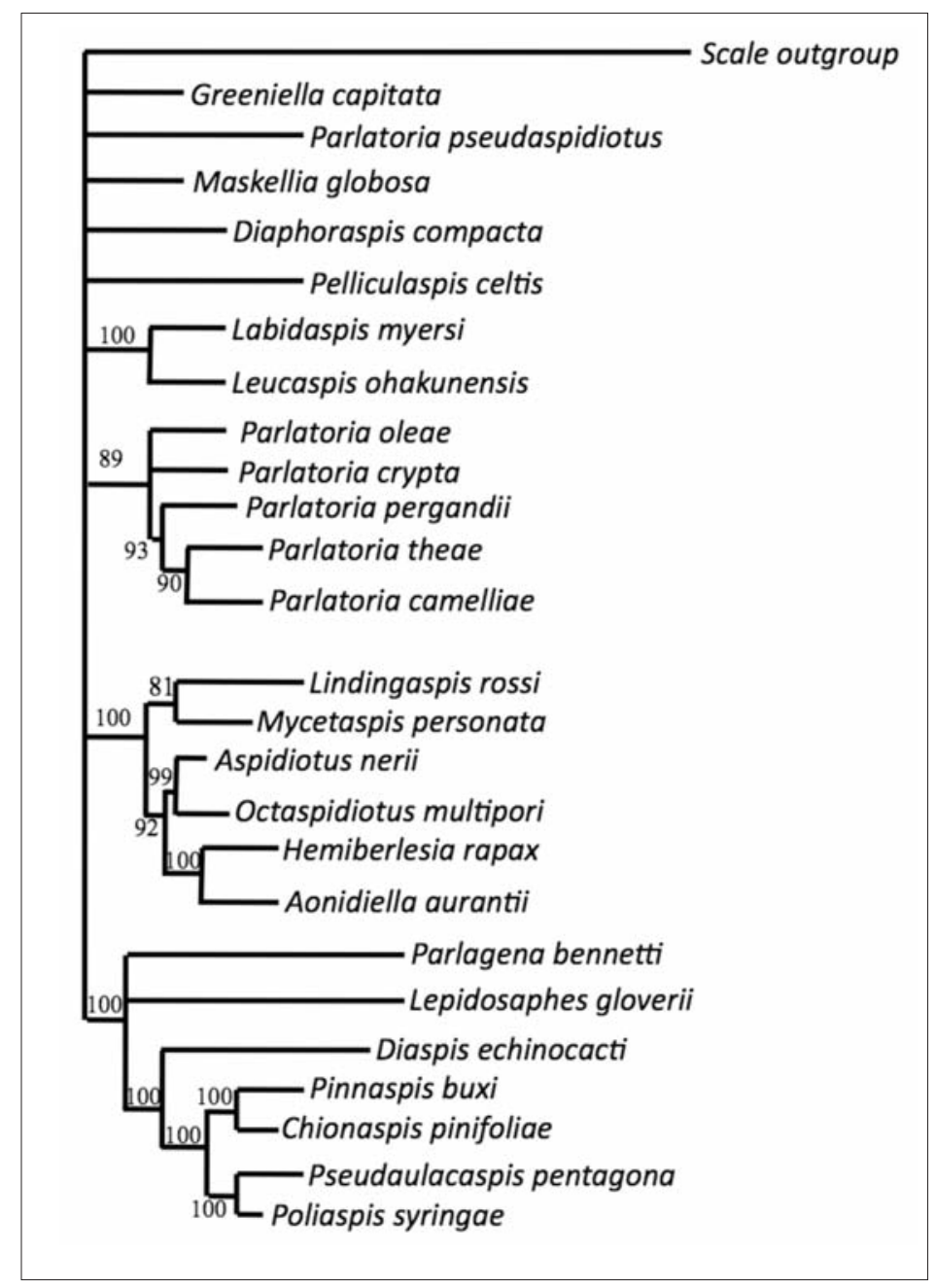

Fig. II - The small ribosomal subunit (16S) rRNA gene from the endosymbiotic bacteria Candidatus Uzinura diaspidicola living within the scale insects. Node labels show Bayesian Posterior Probabilities.

MAFFT: a novel method for rapid multiple sequence alignment based on fast Fourier transform. - Nuc. Acids Res., 30(14): 3059-3066.

Kearse M., Moir R., Wilson A., Stones-Havas S., Cheung M., Sturrock S., Buxton S., Cooper A., Markowitz S., Duran C., Thierer T., Ashton B., Mentues P., Drummond A., 2012 - Geneious Basic: an integrated and extendable desktop software platform for the organization and analysis of sequence data. Bioinformatics, 28 (12): 1647-1649.

Kondo T., Gullan P.J., Watson G.W., Pardey A.E.B., MONTES L.G., 2015 - New distribution and host records for white coconut scale, Parlagena bennetti Williams (Hemiptera: Diaspididae). - Insecta Mundi, 0422: 1-6.

Morse G.E., Normark B.B., 2006 - A molecular phylogenetic study of armoured scale insects (Hemiptera: Diaspididae). - Syst. Entomol., 31(2): 338-349.

MOSQUERA P.F., 1976 - Escamas protegidas más frecuentes en Colombia. - Boletín Técnico, Ministerio de Agrícola Instituto Colombiano Agropecuario, División de Sanidad Vegetal 38: 1-103.

MosQUERA F., 1977 - Estudio preliminar sobre las escamas protegidas (Homoptera: Diaspididae) en cocotero en la isla de San Andrés y su posible control. - Rev. Colomb. Entomol., 3 (1-2): 7-16.

MCKENZIE H.L.A., 1945 - Revision of Parlatoria and closely allied Genera (Homoptera: Coccoidea: Diaspididae). Microentomology, 10 (2): 47-121.

RonQuist F., HUELSENBECK J.P., 2003 - MRBAYES 3: Bayesian phylogenetic inference under mixed models. Bioinformatics. 19: 1572-1574.

Williams D.J., 1969 - A new species of Parlagena McKenzie attacking coconut trees in Trinidad (Hom., Coccoidea, Diaspididae). - Bull. Entomol. Res., 59(01): 97-99. 


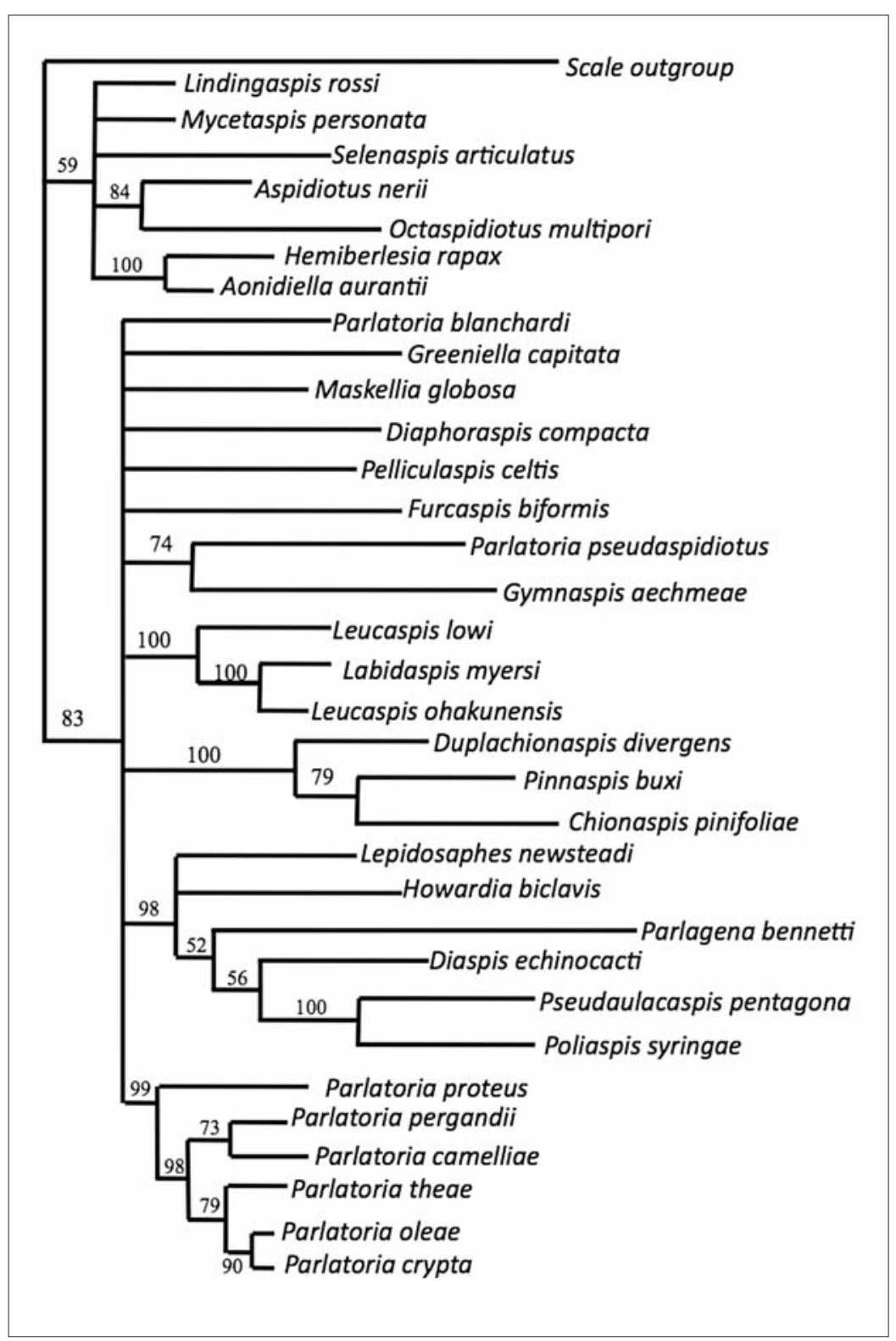

Fig. III - Large ribosomal subunit (28S) rRNA from the armored scale insects. Node labels show Bayesian Posterior Probabilities. 


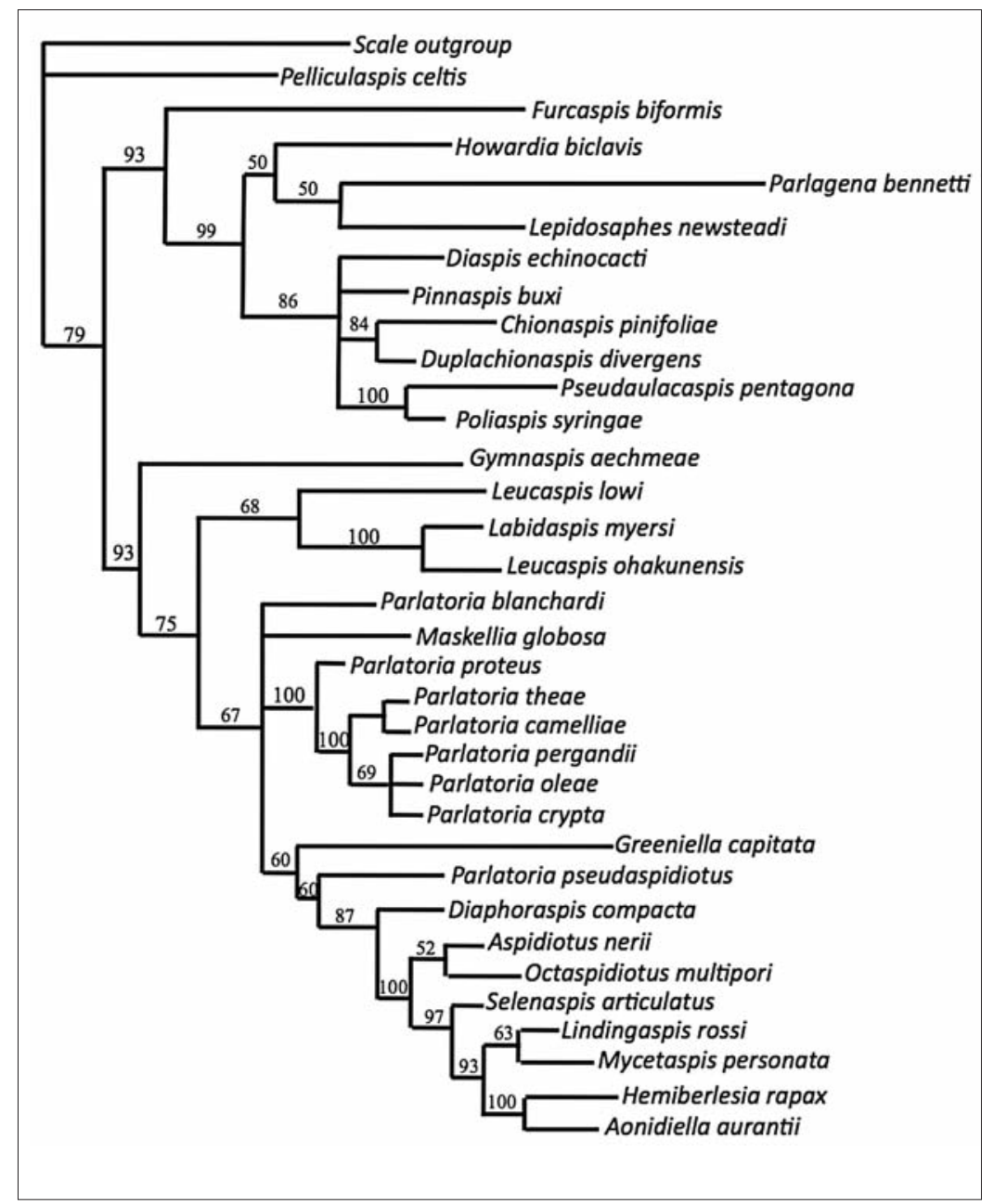

Fig. IV - Elongation Factor 1- alpha (Ef1-alpha) from armored scale insects. Node labels show Bayesian Posterior Probabilities. 